\title{
The Impacts of Climate Change and Adaptation Measures for Rice Production in Central Vietnam: A Pilot in Nui Thanh District, Quang Nam Province
}

\author{
Bui Thi Thu Trang, Nguyen Thi Hong Hanh* \\ Hanoi University of Natural Resources and Environment, 41 Phu Dien, Tu Liem, Hanoi, Vietnam
}

Received 17 January 2017

Revised 19 March 2017; Accepted 28 June 2017

\begin{abstract}
This study analyses the impacts of climate change on rice production and adaptation in Nui Thanh district, Quang Nam province. This study pursues to seek following queries including forecast future rainfall, temperature, rice yield, and analyze adaptation measures to improve rice production under different climate change scenarios in Nui Thanh district, Quang Nam province, Vietnam. The study was based on firstly identification of the problem in the study area followed by collection of secondary data on weather, soil characteristics and crop management. Then the downscaling model was used to predict the temperature and precipitation of the study area in the future by $\mathrm{A} 2$ and $\mathrm{B} 2$ scenarios. The Aquacrop model was used to simulate the yield response. After that, the impact of climate change scenarios on rice yield was analyzed. Lastly, the evaluation for adaptation measure to improve rice production under climate change based on water management was determined. Results show that climate change will reduce rice yield from 1.29 to $23.05 \%$ during the winter season for both scenarios and all time periods, whereas an increase in yield by 2.07 to $6.66 \%$ is expected in the summer season for the 2020s and 2050s; relative to baseline yield. The overall decrease of rice yield in the winter season can be offset, and rice yield in the summer season can be enhanced to potential levels by altering the transplanting dates and by introducing supplementary irrigation. Late transplanting of rice shows an increase of yield by 20 $27 \%$ in future. Whereas supplementary irrigation of rice in the winter season shows an increase in yield of up to $42 \%$ in future. Increasing the fertilizer application rate enhances the yield from 0.3 to $29.8 \%$ under future climates. Similarly, changing the number of doses of fertilizer application increased rice yield by 1.8 to $5.1 \%$, relative to the current practice of single dose application. Shifting to other heat tolerant varieties also increased the rice production.
\end{abstract}

Keywords: Adaptation measure, Aquacrop model, climate change, climate change scenarios, SDSM model.

\section{Introduction}

Vietnam has long seashore, large population and economic activities in coastal zone and

\footnotetext{
*Corresponding author. Tel.: 84-989965118.

Email: nthhanh.mt@hunre.edu.vn

https://doi.org/10.25073/2588-1094/vnuees.4107
}

heavy base on agriculture, forestry and natural resources. Agriculture plays an important role in economy of Vietnam nation, especially in rural areas. As many developing countries, agriculture sector of Vietnam largely depends on weather conditions. Precipitation plays an important role in supplication water source to crops directly. Annual average rainfall of 
Vietnam is more than $2,000 \mathrm{~mm}$ in which monsoon rainfall occupies about $70 \%$ of total annual [1]. At recent years, in the Central and Southern Vietnam, the the frequency of flood has increased significantly, special in rainy season. But most of other regions in country, the drought came due to decrease of rainfall in dry season [1]. Rice has long been Vietnam's traditional food crop and the country's export product. It is about 99.9 percent of Vietnam population eats rice as their main meal. Paddy is grown on 53 percent of the agricultural land in Vietnam, and it represents 64 percent of the sown area crop with 60 percent of labor in rural area. Rice has recently become the second largest export, accounting for 10 percent of total value. Vietnam had successful transformed itself from a chronic rice importer to one of the three largest rice exporters in the world. Nonetheless, climate change directly affected precipitation and temperature, with rise in temperatures leading to water deficit and foods in the future, changing soil moisture status and pest and disease incidence [2].

Parry et al. analysed the global consequences to crop yields, production, and risk of hunger of linked socio-economic and climate scenarios. Potential impacts of climate change are estimated for climate change scenarios developed from the HadCM3 global climate model under the Intergovernmental Panel on Climate Change Special Report on Emissions Scenarios (SRES) A1FI, A2, B1, and B2. Projected changes in yield are calculated using transfer functions derived from crop model simulations with observed climate data and projected climate change scenarios [3]. Tao and Zhang cited the highest benefits were obtained from the development of new crop varieties that are temperature and have high thermal requirements. Based on simulations, at North China Plain (NCP) it was found that for the high temperature sensitive varieties, early planting of the crop is the effective option for reducing the yield loss from climate change in the region. Also it was concluded that for high temperature tolerant varieties, late planting is a good adaption option moreover the spatial analysis shows the relative contributions of adaptation options should be region and variety of crop specific as the adaptation varies geographically and crop variety [4].

Reidsma et al. analysed the adaptation of farmers and regions in Europe to the prevailing climate change, climate variability and climatic conditions in the last decade. The research concludes that, the impacts on the crop yields cannot be translated to the impacts on the farmers' income, since farmers adapt by changing the crop rotations and inputs and the incomes are also dependent on the subsidies by the government. Secondly, the observed impacts of climate change on the spatial variability on the yield and income is lower in warmer climates as compared to temporal variability in climate in the places where there is heterogeneity in the crops grown. Thirdly climate change and variability impacts are dependent on the farm characteristics (e.g. size, intensity and land use) which have ultimate influence on adaptation and management. As different farm types adapts differently, hence a larger diversity in the farm types reduces the impacts of the climate variability at a regional level. Finally from the study, they concluded that the yield and the farmers' income in the future is mainly dependent on the adaptation practices being followed which can reduce the potential impacts of climate change. Farmers continuously adapt to changes, which affects the current situation as well as future impacts [5]. Geerts used AquaCrop to derive deficit irrigation (DI) schedules. In this study, they use the AquaCrop model to simulate crop development for long series of historical climate data. Subsequently they carry out a frequency analysis on the simulated intermediate biomass levels at the start of the critical growth stage, during which irrigation will be applied. From the start of the critical growth stage onwards, they simulate dry weather conditions and derive optimal frequencies (time interval of a fixed net application depth) of irrigation to avoid drought 
stress during the sensitive growth stages and to guarantee maximum water productivity. By summarizing these results in easy readable charts, they become appropriate for policy, extension and farmer level use. If applied to other crops and regions, the presented methodology can be an illustrative decision support tool for sustainable agriculture based on DI [6].

Climate change severe affects to the crops yield and finally to ramp up poverty in Vietnam. Therefore, it is necessary to seek the solutions to adapt to climate change, special for famer life and their agriculture production. The frame of this paper focus finding out impacts of climate change on rice production in Nui Thanh district of Quang Nam province in center of Viet Nam. The area often have tremendous catastrophically natural hazard by flood and typhoon. The main objective of this research was to forecast future rainfall, temperature and rice yield, and analyze adaptation measures to improve rice production under different climate change. The specific objectives are: to forecast rainfall, temperature on the future in the study area under climate change condition; to predict crop yield in future under climate change scenarios; to evaluate adaptation measures to improve rice production under climate change based on water management.

\section{Materials and methods}

\subsection{Study area}

The research was conducted in Nui Thanh district to typify for a coastal sub-region in order to understanding the impacts of climate change on rice production. Nui Thanh is the last district to the southward of the province and is adjacent to Quang Ngai province. With diverse topography: coastal zone, plain zone and mountainous zone, Nui Thanh is hard hit by storm, drought in the coastal area, flood in mountainous area, plain area. The hazards robbed the life and a lot of property in this district in the past years. Nui Thanh is assessed as one of the most serious damaged district by the hazard of Quang Nam province [7]. Special, the important criteria for choice of study site are as follows: The high rate of population cultivates agriculture as major livelihood; not only storm and food but also the study site is affected by other irregular climate factors, such as temperature, rainfall.

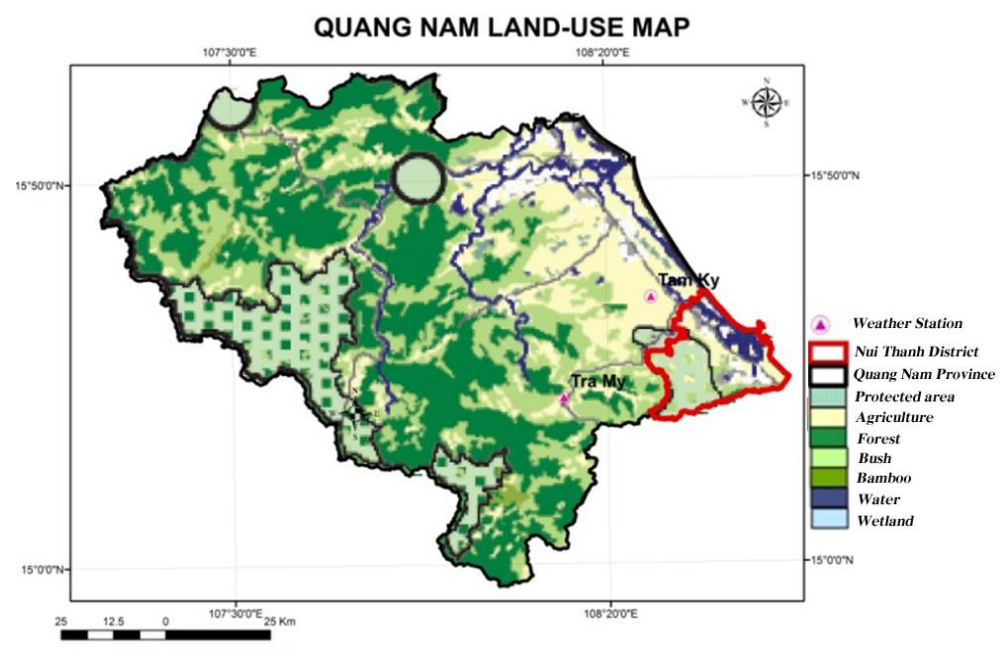

Figure 1. Quang Nam land use map and Nui Thanh hydrology. 


\subsection{Climate data}

The climate data were collected from Vietnam meteorological Department, with the Tra My and Tam Ky stations (the weather stations nearest Nui Thanh), where the experiments are performed. The data consists of daily weather data including rainfall, maximum and minimum temperature (from year 1961 to 2000), average monthly weather data including rainfall, maximum temperature, minimum temperature, sunshine hours, wind speed and relative humidity (from year 2000 to 2010).

\subsection{Future climate scenarios}

The future climate scenarios was downloaded from the Global Climate Model HadCM3 (Hadley Centre Coupled Model, version 3) developed by Met Office Hadley Centre, England. (Website: http://www.cccsn.ec.gc.ca/?page=sdsm). The high resolution data was developed considering the world growth forced by level of atmospheric $\mathrm{CO}_{2}$ concentration according to IPCC SRES A2 scenario (which is one of the most pessimistic projections) and B2 (another pessimistic projection but population growth rate lower than A2). Then the data was downscaled to the regional level by using SDSM (Statistical Downscaling Model) for the study area. The downscaled data for the period of 2014-2040, 2041-2070 and 2071- 2090 was used for the grid which falls nearest to the study area.

\subsection{Agricultural data}

The data of rice crop was collected from Quang Nam Department of Agriculture and Rural Development and Agriculture Division under Nui Thanh District People's Committee as secondary sources. The data included major rice varieties, transplanting date, density of plants, flowering date (anthesis date), senescence date, maturity date, and method of sowing, irrigated schedule and the rice yields. The information data is about two majors' rice varieties grown in the Quang Nam province: CH207 and TBR1 for period 2001-2010. The researcher assumed that the treatment and organic manures was provided full in the field. Other side, field surveys of smallholder farmers was conducted in three communes: Tam Hoa, Tam Hiep and Tam Xuan II about one month. 30 smallholder farmers were randomly selected from three communes and interview by trained assessors on a set of questions designed in a questionnaire. The questions were aimed to obtain information on the: indigenous farming practices, variety preferences and attitude to forwards modification of traditional farming method and crop varieties.

\subsection{Soil properties data}

The information about physical and chemical properties of the soil is collected from Quang Nam state land and development section. The data required are soil texture, $\mathrm{pH}$, phosphorous, nitrogen, carbon and carbon exchange capacity.

\subsection{Model}

\section{Downscaling of GCM data by SDSM}

The general principle of downscaling is to relate large scale predictor variables to sub-grid or station level climate variable. This study used the statistical downscaling (SD) method to transfer large scale GCM grid data to local scale station data which are required to feed hydrological models for the simulation of future scenarios of climate change impact. The statistical downscaling model (SDSM) version 4.2.9 developed by Wilby et al. (2000) is use in this study. This model used the principle of developing multiple linear regression transfer functions between large-scale predictors and local climate variables (predictand) and these transfer functions were used for downscaling future climate predicted by GCMs. This study used the period of 1961-1990 as the base period for model calibration and validation. This period taken because most of the GCMs provide their projected climatic data starting 
from 1961 and in most of the study region observed climatic data are also available for this period. While using the modeled climate results for scenario construction, the base line serves as reference period from which the future changes are calculated. Downscaling with SDSM includes of four main steps: screening of large scale climatic variables (predictors), calibration of transfer functions, validation of downscaling model and scenario generation generation.

\section{ETo calculator}

The weather data required by AquaCrop model are daily values of minimum and maximum air temperature, reference crop evapotranspiration (ETo), rainfall and mean annual carbon dioxide concentration $\left(\mathrm{CO}_{2}\right)$. ETo was estimated using ETo calculator using the daily maximum and minimum temperature, wind speed at $2 \mathrm{~m}$ above ground surface, solar radiation and mean relative humidity $(\mathrm{RH})$. The weather parameters were collected from automatic weather station located at a distance of $13 \mathrm{~m}$ above sea level.

\section{Calibration and Validation of Aquacrop model}

Calibration or fine tuning of the AquaCrop model was run after preparing the input data files consist of meteorological data, precipitation, evapotranspiration, irrigation, plant and soil information from the field experiment during 2001 to 2010 for two crop seasons. The model calibration was conducted by changing the model parameters and based on best matching between the output and observed data. The simulating value of model predicted the output the yield, biomass and canopy cover (CC) which used to compare with measured yield and biomass of the experimental plot. The difference between the model predicted and experimental data was minimized by using trial and error approach in which one specific input variable was chosen as the reference variable at a time and adjusting only those parameters that were known to influence the reference variable the most. The procedure is repeated to arrive at the closest match between the model simulated and observed value of the experiment for each treatment combination. In this study, the winter crop was performed based on rainfall. However, the irrigated experiments were performed on the summer crop. In some cases such as upper and lower thresholds for canopy expansion, upper threshold for stomata closure and canopy senescence stress the recommended default value by model guidelines, was considered.

\section{Results and discussion}

\subsection{Projection of future climate}

\section{Projection of future temperature}

In this part, the SDSM was used to project the change in maximum and minimum temperature in three periods: 2014-2040, 20412070 and 2071-2090 relative to base period 1961-1990. The results show that the highest rise in maximum temperature will be $3.69^{\circ} \mathrm{C}$ and the lowest rise will be $0.93^{\circ} \mathrm{C}$ by period 2014-2040 according to scenario A2. The scenario B2 indicates lower rate of rise with average value of $1.85^{\circ} \mathrm{C}$ relative to baseline period. The highest rise in minimum temperature will be $1.72^{\circ} \mathrm{C}$ by period 2071 2090 and the lowest rise will be $0.35^{\circ} \mathrm{C}$ by period 2014-2040 according to scenario A2. The highest rise in minimum temperature will be $1.29^{\circ} \mathrm{C}$ by period $2071-2090$ and the lowest rise will be $0.39^{\circ} \mathrm{C}$ by period $2014-2040$ according to scenario $\mathrm{B} 2$. The average change in maximum and minimum temperature for SRES A2 and B2 scenarios are presented in figure 2 .

The average of monthly maximum temperature and minimum temperature for three future periods compared to baseline period with A2 and B2 scenarios are showed in figure 3. The temperature presents considerably most similar trends for two scenarios. 


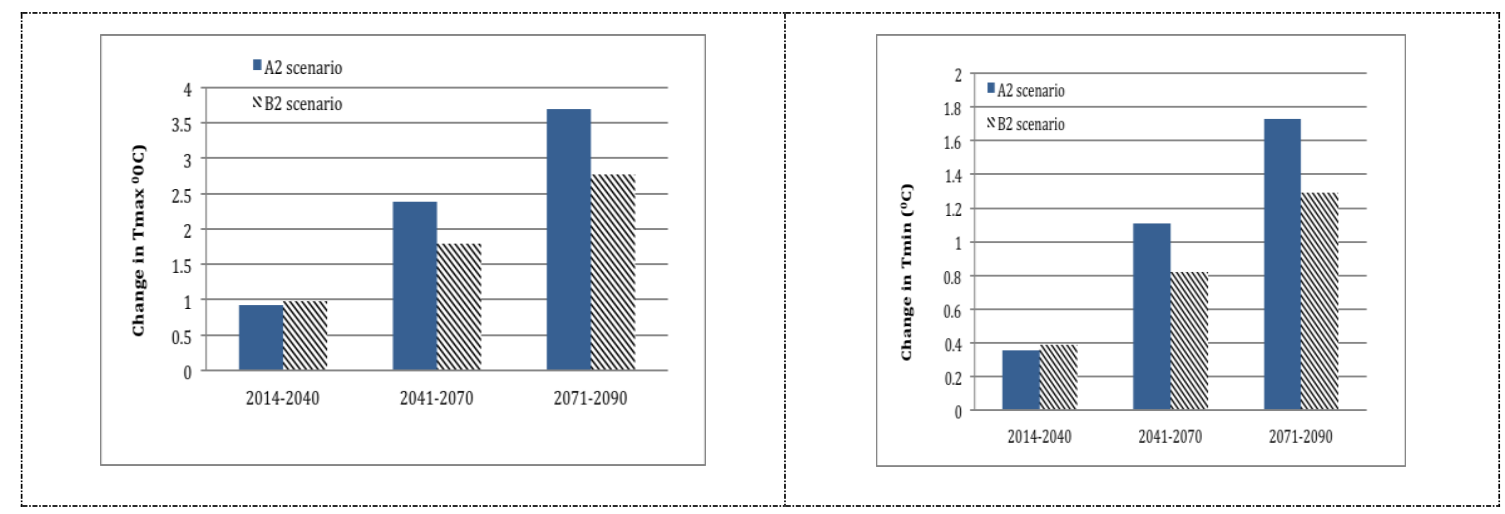

Figure 2. The changing in the average annual of maximum and minimum temperature.
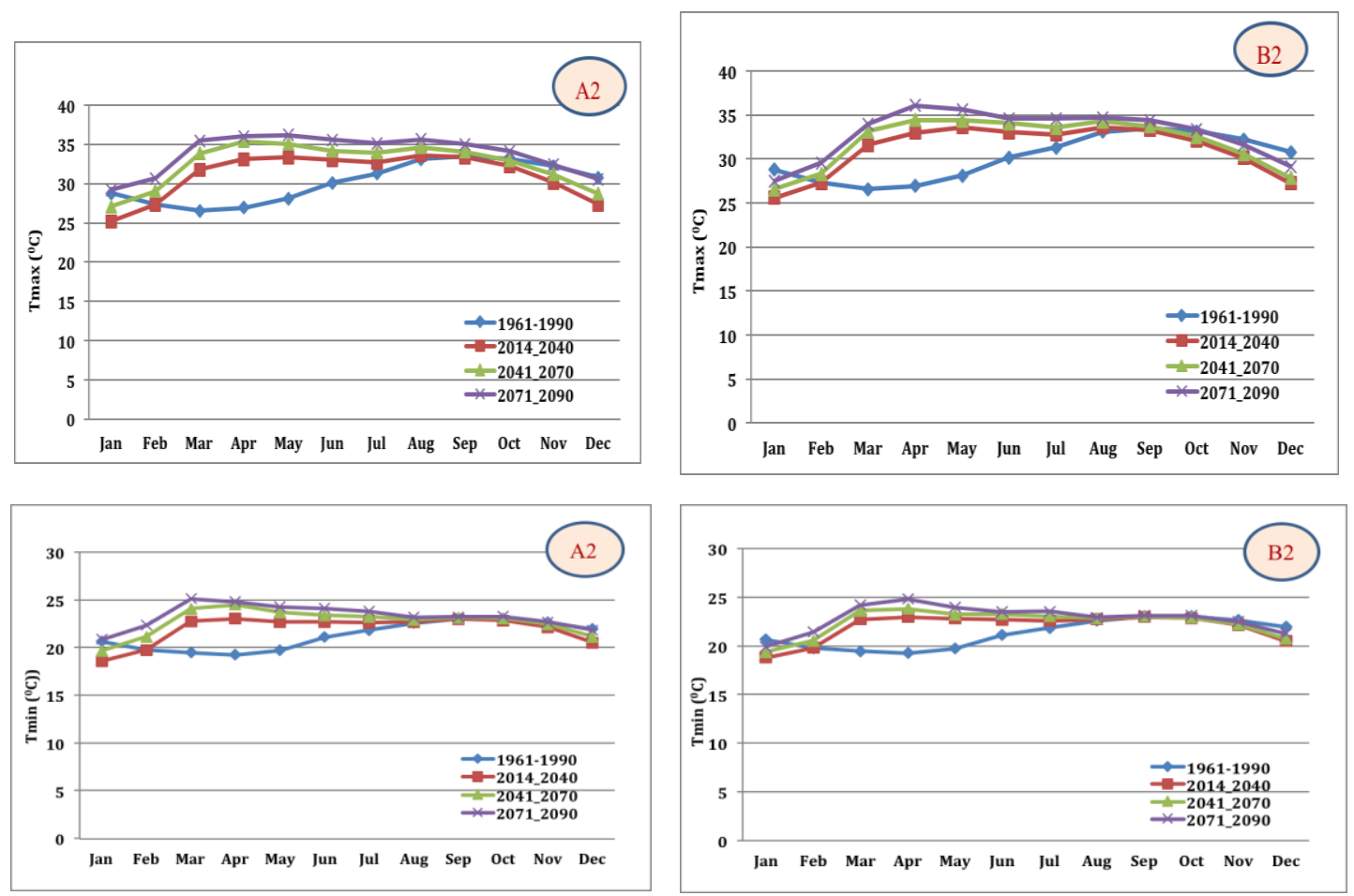

Figure 3. Monthly Tmax and Tmin average for 30 years interval for A2 and B2

\section{Projection of future precipitation}

In this part, the SDSM was used to project the precipitation in three periods: 2014-2040, 2041-2070 and 2071-2090 relative to base period 1961-1990. Figure 4 shows the relative changes in the precipitation for the study area projected for A2 and B2 scenarios for periods 2014-2040, 2041-2070 and 2071-2090 as compare to baseline period of 1961-1990.
Scenario A2 shows increase in average annual precipitation by $0.66, \quad 5.51$ and $9.75 \%$ respectively for periods 2014-2040, 2041-2070 and 2071-2090. Scenario B2 has slightly higher increase rate on periods 2014-2040 and 20712090 , there are about of 1.83 and $5.62 \%$. But it is lower increase than scenario A2 in period 2041-2070, it is about $3.47 \%$. 


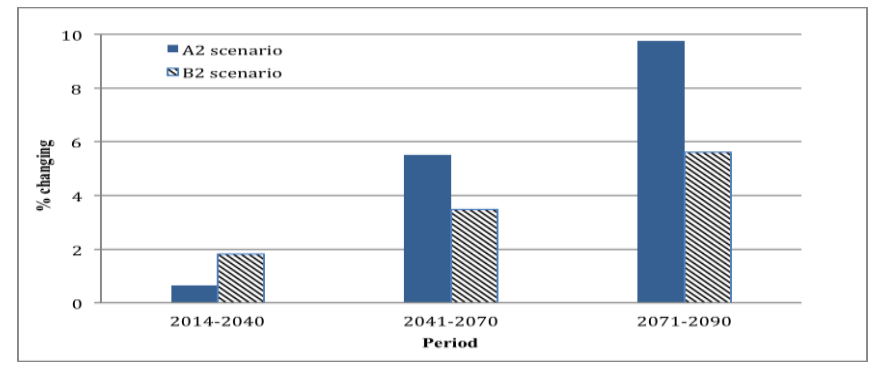

Figure 4. The changing in the average annual of precipitation for A2 and B2.

The projected precipitation does not show any fixed trend for both scenarios. There is wide variation at temporal and spatial scale throughout the basin. The figure 5 shows the changing in monthly precipitation for the study area projected for $\mathrm{A} 2$ and $\mathrm{B} 2$ scenarios for periods 2014-2040, 2041-2070 and 2071-2090 compared to baseline period of 1961-1990. Scenario A2 and scenario B2 are most the same the trend. Those figures show decrease of precipitation during most of rainy season and increase during dry season. The precipitation strong decreases on January and April which is about 44.41 to $57.90 \%$. The precipitation higher increases on June, it is over $150 \%$. But the total precipitation of June is not very high; therefore the amount of changing is not too large. From the $\%$ changing in there figures, it is impress that the impact of climate change is very serious on the end of XXI century.
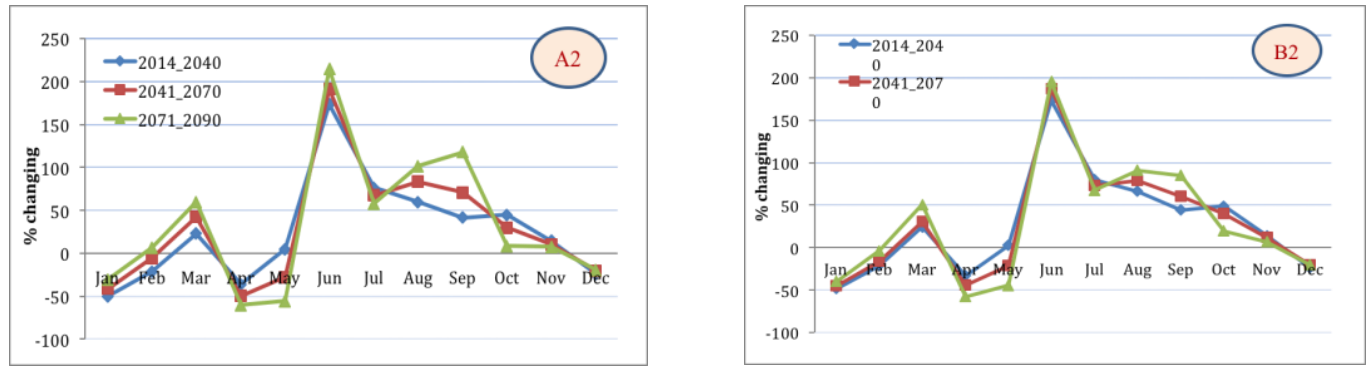

Figure 5. Variation in change of precipitation for A2 and B2 scenarios compared to the baseline period (1961-1990)

\subsection{Forecast the yield in future period by using Aquacrop model}

The rainy season in the northern delta usually begins in May-June and end on October-November. In the central province, rainy season comes later, the large amount of rainfall usually during time of NovemberDecember. From the output of SDSM for the future climate, the precipitation higher increases on June to September, but the total rainfall during that time is not high, other case, the total rainfall is high during the months from October to March, but the future precipitation decrease on December, January, February, April and May. Therefore, the researcher recognized that there would be difference trend impact to future yield between the crop cycle Winter-Spring and Summer-Autumn. That why, the simulation of yield have done for two crop seasons to discover the impact of climate change to the yield.

The figure 6 presents the percentage change in rice for A2 and B2 scenarios for 2014-2040, 2041-2040 and 2071-2090 relative to 2001-2010 simulated by Aquacrop model during winter crop and summer crop. 

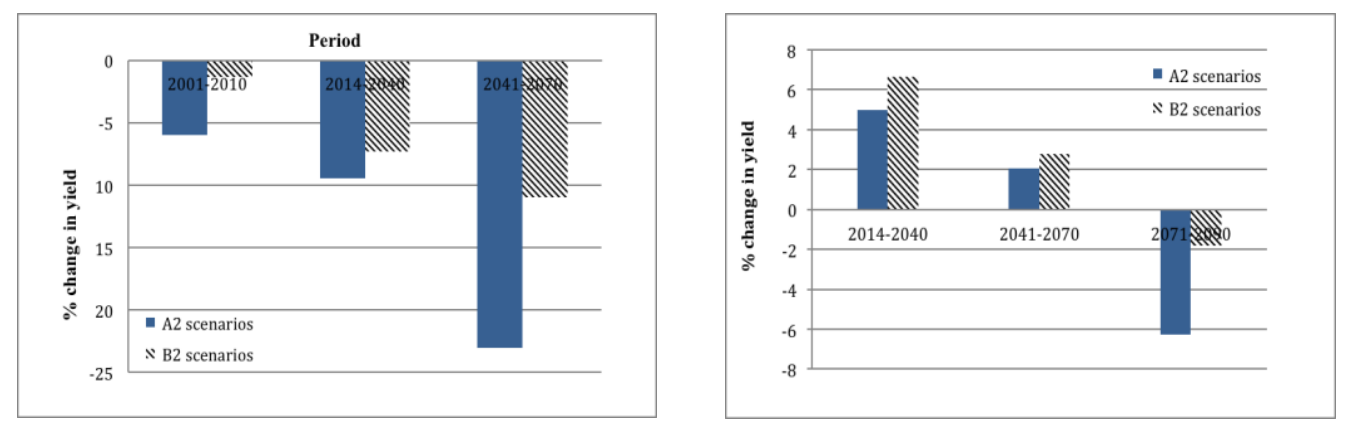

Figure 6. Percentage change in rice yields with A2 and B2 scenarios for periods 2014-2040,

2041-2040 and 2071-2090 relative to 1961-1990 during (a) Winter crop and (b) Summer crop.

For winter crop, with rainfed when calibration Aquacrop model, all of future periods the yield will reduce. The yield significantly decreases during period 20712090 with both A2 and B2 scenarios. The reason of forecasted yield reduces significantly from the baseline period this may be due to the effect of the reduced rainfall and the stress due to increased temperature during flowering. Similarly the biomass also shows a reducing trend for both scenarios. The yield simulated by Aquacrop express a decline 5.97 to 23.05 and 1.29 to 10.96 percent compared to the yield of the baseline period for A2 and B2 scenarios respectively. Therefore, for winter crop season, farmer should supplementary irrigation water applied using furrow method for three times at 10 days interval starting, flowering and grain filling to reach the optimum yield in the future periods.

For the summer crop, with baseline period 2001-2010, the model calibrated for irrigated crop. However, the rainfall significant increase on this season in the future. Therefore, the water available will be enough for crop for some periods. Then, the yield increase about $5 \%$ and $6.67 \%$ for period 2014-2040, $2 \%$ and $2.78 \%$ for 2041-2070 with A2 and B2 scenarios respectively. The yield will reduce $1.83 \%$ and $6.26 \%$ for $2071-2090$ with A2 and B2 scenarios respectively. During period 20012010, to obtain the high yield or do not lose yield rice, the farmer had to supplement irrigation water. However, the output of SDSM for future climate changes scenarios. The rainfall will increase starting from June until September. This is the period of summer crop rice crop. Therefore, the additional irrigation for rice in the forecast period is increased. So the model can calibration for rainfed yield in the future period without additional water, which is perfectly consistent with the results predicted by SDSM model.

\subsection{Agricultural adaptation measures}

Impacts of supplementary irrigation on rice yield

Supplementary irrigation water applied using furrow method in incremental amount of $20 \mathrm{mmm}, 40 \mathrm{~mm}, 40 \mathrm{~mm}, 80 \mathrm{~mm}$ and $100 \mathrm{~mm}$. Each irrigation level was applied four times at 20 days interval starting, 20 days before flowering date to coincide with the critical stages of rice growth, flowering and grain filling. The figure below explains the percentage change in yield under supplementary 20, 40, 60, 80 and $100 \mathrm{~mm}$ for 4 applications as compared to rainfed crop (for winter crop) and irrigated crop (for summer crop) under A2 scenario. The results shows that for all future periods, in winter crop, the optimum amount of supplementary irrigation are about $400 \mathrm{~mm}$ in four applications and this would increase the yield by $24.13 \%$ in $2014-$ 2040 , by $27.45 \%$ in $2041-2070$ and by $42.1 \%$ in 2071-2090. For the summer crop season, the optimum amount of supplementary irrigation is 
about $320 \mathrm{~mm}$ and this would increase the yield by $2.32 \%$ in $2014-2040$, by $2.48 \%$ in 2041 2070 and by $2.52 \%$ in 2071-2090. The application for irrigation water in summer crop

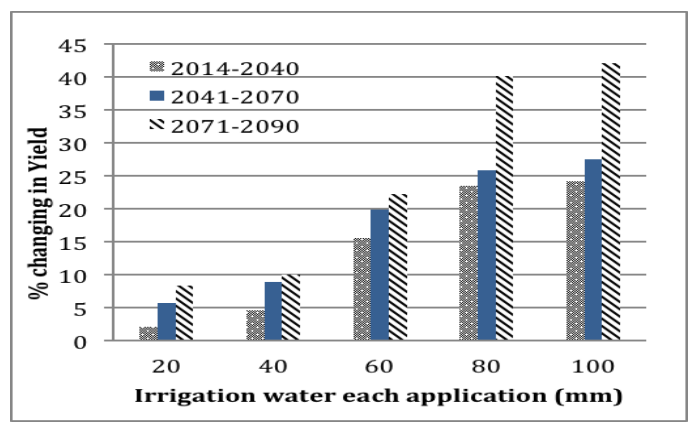

(a) rainfed does not increase the yields significantly because of this season has fairly enough rainfall. The result shows there are good relative with the output of SDSM model.

Figure 7. Impact of supplemental irrigation on rice for A2 scenario (a) Winter crop (rainfed) and (b) Summer crop (irrigation)

The figure 8 below explains the percentage change in yield under supplementary 20, 40, 60, 80 and $100 \mathrm{~mm}$ for 4 applications as compared to rainfed crop (for winter crop) and irrigated crop (for summer crop) under B2 scenario. The results show that for all future periods, in winter crop, the optimum amount of supplementary irrigation is about $400 \mathrm{~mm}$ in four applications and this would increase the yield by $20.13 \%$ in $2014-2040$, by $30.45 \%$ in $2041-2070$ and by
$32.81 \%$ in $2071-2090$. For the summer crop season, the optimum amount of supplementary irrigation is about $320 \mathrm{~mm}$ and this would increase the yield by $2.28 \%$ in $2014-2040$, by $2.35 \%$ in $2041-2070$ and by $2.48 \%$ in 2071 2090. The application for irrigation water in summer crop does not increase the yields significantly because of this season has fairly enough rainfall. The result shows there are good relative with the output of SDSM model.

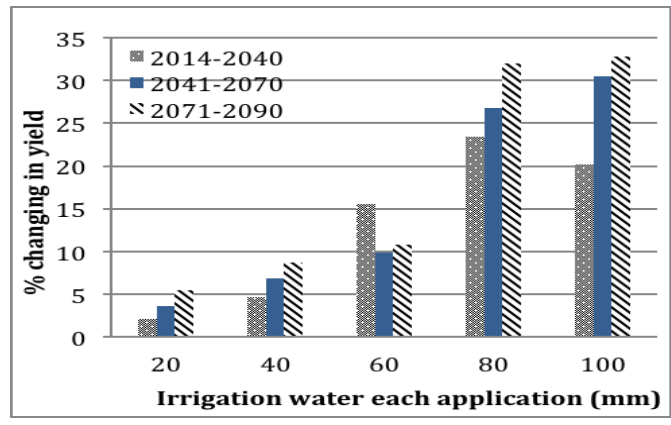

(a) rainfed

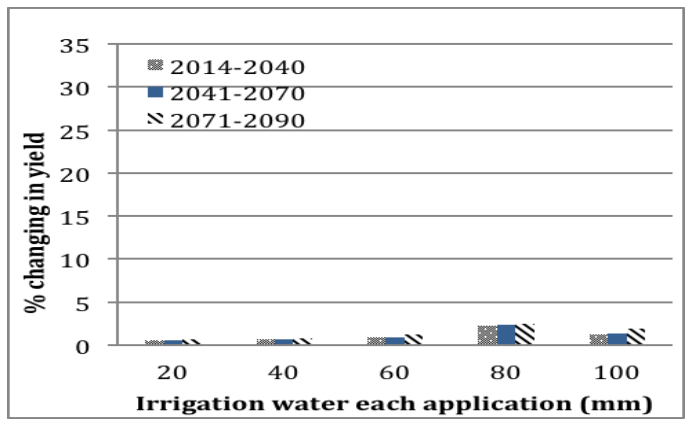

(b) irrigation

Figure 8. Impact of supplemental irrigation on rice for B2 scenario(a) Winter crop and (b) Summer crop 


\subsubsection{Impact of changing sowing date on} rice yield

In this section, the date for transplanting was changed with different dates to determine which date is best to gain the optimum yield. The simulations were run with the dates around one week, two week, three weeks... compared with the current transplanting date. Figure 3.8 shows the percentage change in yield with different transplanting dates for $\mathrm{CH} 207$ and TBR1 with A2 scenario. For winter crop, the result shows that the transplanting date of $25^{\text {th }}$ February is the optimum for future period, which can increase the yield up to $18.14 \%$, $19.87 \%$ and $20.43 \%$ for $2014-2040,2041-2070$ and 2071-2090 respectively. Probably this due to the reason that, the precipitation is decreased during December to January, then if the transplanting is during this time the yield would reduce. From the second week of February, the rainfall increase, it is better to transplanting from $10^{\text {th }}-30^{\text {th }}$ February. For summer crop, the result shows that the transplanting date of $11^{\text {st }}$ June is the optimum for period 2014-2040 and 2041-2070, which can increase the yield up to $27.78 \%$ and $26.43 \%$ respectively. With period 2071-2090, the optimum is $18^{\text {th }}$ June, which can increase the yield up to $24.86 \%$. Then, for summer crop, it is better to transplanting from $3^{\text {rd }}-18^{\text {th }}$ of June.
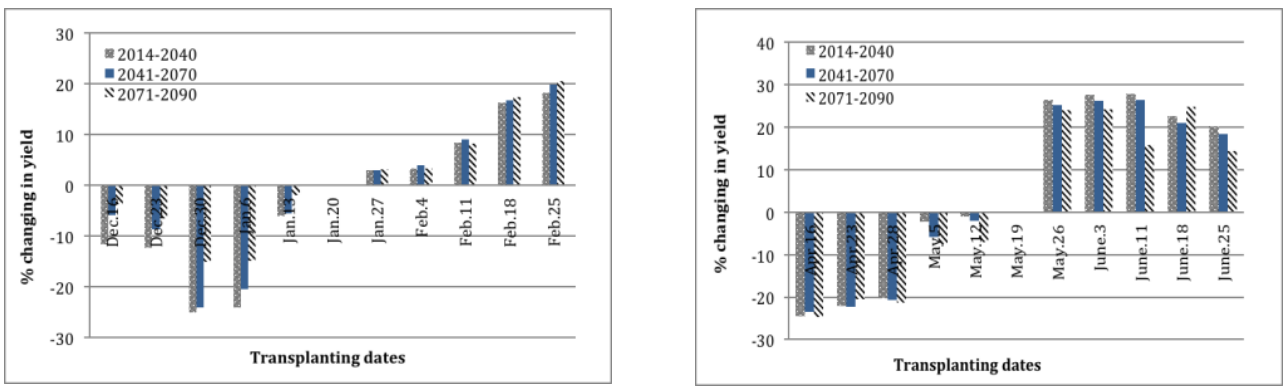

Figure 9. Percentage change in yield with different dates for A2 scenario (Jan $20^{\text {th }}$ and Mar $19^{\text {th }}$ are current planting date): (a) Winter crop and (b) Summer crop.
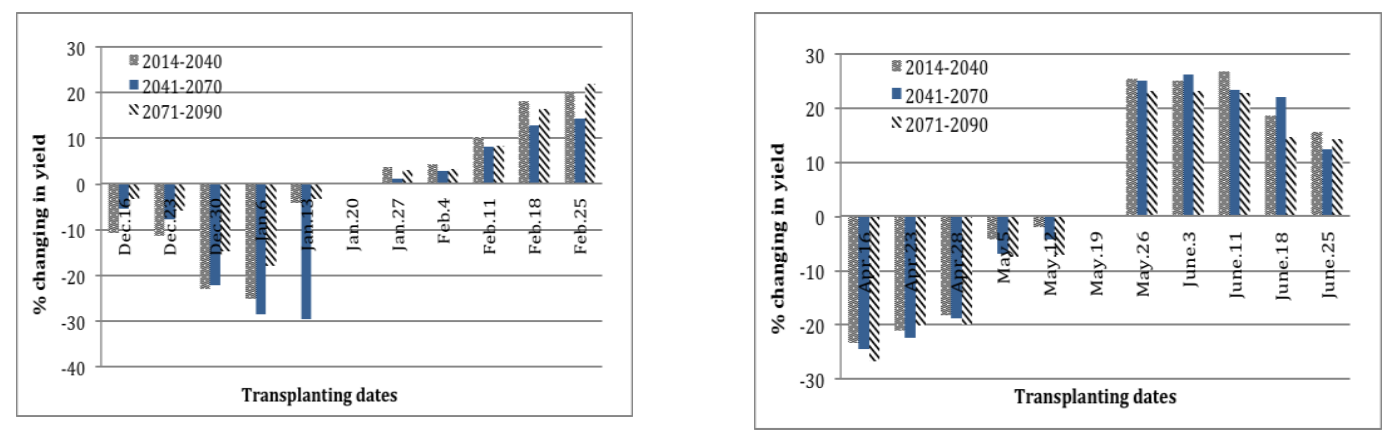

Figure 10. Percentage change in yield with different dates for B2 scenario (Jan $20^{\text {th }}$ and Mar $19^{\text {th }}$ are current planting date): (a) Winter crop and (b) Summer crop.

With B2 scenario, for winter crop, the result shows that the transplanting date of $25^{\text {th }}$ February is the optimum for future period, which can increase the yield up to $20.34 \%$,
$14.37 \%$ and $22.94 \%$ for $2014-2040,2041-2070$ and 2071-2090 respectively. Probably this due to the reason that, the precipitation is decreased during December to January, then if the 
transplanting is during this time the yield would reduce. From the second week of February, the rainfall increase, it is better to transplanting from $10^{\text {th }}-30^{\text {th }}$ February. For summer crop, the result shows that the transplanting date of $11^{\text {st }}$ June is the optimum for period 2014-2040 and 2071-2090, which can increase the yield up to $26.72 \%$ and $22.86 \%$ respectively. With period 2041-2070, the optimum is $3^{\text {rd }}$ June, which can increase the yield up to $26.18 \%$. Then, for summer crop, it is better to transplanting from $26^{\text {th }}$ May to $11^{\text {th }}$ June. Figure 10 shows the percentage change in yield with different transplanting dates for $\mathrm{CH} 207$ and TBR1 with B2 scenario.

\section{Conclusions}

In this paper the impact of climate change on paddy irrigation required and volumetric irrigation water demand have been presented. The results from the present study conclude that:

The minimum temperature will increase about $0.35^{\circ} \mathrm{C}, 1.10^{\circ} \mathrm{C}$ and $1.72^{\circ} \mathrm{C}$ in periods 2014-2040, 2041-2070 and 2071-2090 respectively with $\mathrm{A} 2$ scenario; and increase about $0.39^{\circ} \mathrm{C}, 0.81^{\circ} \mathrm{C}$ and $1.29^{\circ} \mathrm{C}$ in periods 2014-2040, 2041-2070 and 1971-2090 respectively for $\mathrm{B} 2$ scenario to compare with the period minimum temperature is $21.6^{\circ} \mathrm{C}$. In case of maximum temperature, for $\mathrm{A} 2$ scenario, the base period temperature is $30.110 \mathrm{C}$ which will increase $0.93^{\circ} \mathrm{C}$ (in period 2014-2040), $2.38^{\circ} \mathrm{C}$ (in period $2041-2070$ ) and $3.69^{\circ} \mathrm{C}$ (in period 2071-2090) in the future; and for B2 scenario, the maximum temperature increased $0.98^{\circ} \mathrm{C}$ (in period $2014-2040$ ), $1.79^{\circ} \mathrm{C}$ (in period 2041-2070) and $2.78^{\circ} \mathrm{C}$ (in period 2071-2090).

The annual precipitation may increase from $0.66 \%$ to $9.75 \%$ for $\mathrm{A} 2$ scenario and from $1.83 \%$ to $5.62 \%$ for B2 scenario. The precipitation will be decrease during rainy season and increase from mid of dry season.

When using Aquacrop for winter crop by rainfed calibrate. For all of future period the yield will reduce. The yield significantly decreases during period 2071-2090 with both A2 and B2 scenarios. The yield simulated by Aquacrop express a decline 5.97 to 23.05 and 1.29 to $10.96 \%$ compared to the yield of the baseline period for A2 and B2 scenarios respectively. With summer crop, for baseline period 2001-2010, the model calibrated for irrigated crop. However, the rainfall significant increase on this season in the future. Therefore, the water available will be enough for crop for some periods. Then, the yield increase about $5 \%$ and $6.67 \%$ for period 2014-2040, $2 \%$ and $2.78 \%$ for $2041-2070$ with A2 and B2 scenarios respectively. The yield will reduce $1.83 \%$ and $6.26 \%$ for 2071-2090 with A2 and B2 scenarios respectively.

For winter crop, optimum of supplementary irrigation is at $400 \mathrm{~mm}$ which would increase the yield about $24.13 \%$ to $42.1 \%$ with A2 scenario and about $20.13 \%$ to $32.81 \%$ with B2 scenario. The application for irrigation water in summer crop does not increase the yields significantly, the optimum amount of supplementary irrigation is about $320 \mathrm{~mm}$ and this would increase the yield by $2.32 \%$ to $2.52 \%$ with A2 scenario and $2.28 \%$ to $2.48 \%$ with B2 scenario.

Changing the transplanting dates can increase the yield to higher extent under climate change scenarios. The yield obtains higher if transplanting during $10^{\text {th }}-30^{\text {th }}$ February for winter crop, and from $26^{\text {th }}$ May to $18^{\text {th }}$ June for summer crop.

\section{References}

[1] Thuc, Tran., 2010. Impacts of climate change on water resources in the Huong River basin and adaptation measures. VNU Journal of Science, Earth Sciences 26 (2010), pp. 210-217.

[2] Chinvanno, S.,2010. Climate change adaptation as a development strategy: Amajor challenge for Southest Asian Countries. Southeast Asia START Regional Center, Chulalongkon University, Thailand. 
[3] Parry, M. L., Rosenzweig, C., Iglesias, A., Livermore, M., Fischer, G., 2004. Effects of climate change on global food production under SRES emissions and socio-economic scenarios. Global Environmental Change 14 (2004) 53-67.

[4] Tao, F., Zhao, Z., 2010. Adaptation of maize production to climate change in North China Plain: Quantify the relative contributions of adaptation options. European Journal of Agronomy, 33: 103-116.
[5] Reidsma, P., Ewert, F., Lansink, A. O., Leemans, R., 2010. Adaptation to climate change and climate variability in European agriculture: The importance of farm level responses, European Journal of Agronomy, 32: 91-102.

[6] Geerts, S., Raes, G., and Garcia, M., 2010. Using Aquacrop to derive deficit irrigation schedules. Agricultural Water Management.

[7] Tran Duc Vien., 2011. Climate change and its impacts on agriculture in Vietnam. J. ISSAAS Vol.17, No.1/17-21 (2011).

\title{
Tác động của biến đổi khí hậu và các biện pháp thích ứng đối với sản xuất lúa tại khu vực miền Trung Việt Nam: thí điểm tại huyện Núi Thành, tỉnh Quảng Nam
}

\author{
Bùi Thị Thu Trang, Nguyễn Thị Hồng Hạnh \\ Đại học Tài nguyên và Môi truờng Hà Nội, 4lA Phú Diễn, Tù Liêm, Hà Nội, Việt Nam
}

Tóm tắt: Nghiên cứu này phân tích tác động của biến đổi khí hậu đối với sản xuất lúa và giải pháp thích nghi ở huyện Núi Thành, tỉnh Quảng Nam. Các bước tiến hành trong nghiên cứu là thu thập số liệu thứ cấp gồm dữ liệu về thời tiết, đặc điểm đất đai và quản lý cây trồng. Sau đó, sử dụng mô hình thu hẹp SDSM để dự đoán nhiệt độ và lượng mưa của khu vực nghiên cứu trong tương lai bởi các kịch bản $\mathrm{A} 2$ và $\mathrm{B} 2$. Sử dụng mô hình cây trồng Aquacrop để mô phỏng năng suất. Các kết quả đầu ra của SDSM làm đầu vào cho mô hình AQuacrop. Phân tích tác động của các kịch bản biến đổi khí hậu đến sản lượng lúa, từ đó đề ra các biện pháp thích ứng để cải thiện năng suất lúa theo kịch bản biến đổi khí hậu. Kết quả cho thấy biến đổi khí hậu sẽ làm giảm năng suất lúa $1,29-23,05 \%$ trong mùa Đông cho cả hai kịch bản với tất cả các khoảng thời gian, trong khi đó năng suất dự kiến tăng khoảng 2,07-6,66\% trong mùa Hè cho năm 2020 và 2050. Sự suy giảm tổng năng suất lúa vào mùa Đông có thể được bù đắp, và năng suất lúa trong mùa Hè có thể được tăng cường đến mức tiềm năng bằng cách thay đổi ngày cấy và bổ sung hệ thống thủy lợi. Thay đổi ngày cấy muộn hơn có thể tăng năng suất lên tới 20$27 \%$. Bên cạnh đó, bổ sung thuỷ lợi trong mùa Đông có thể tăng năng suất lên đến $42 \%$. Tăng tỷ lệ sử dụng phân bón có thể tăng năng suất $0,3-29,8 \%$. Tương tự như vậy, thay đổi liều lượng sử dụng phân bón có thể tăng năng suất lúa từ 1,8 đến $5,1 \%$. Chuyển sang giống chịu nhiệt khác cũng làm tăng sản xuất lúa.

Tư khóa: Biện pháp thích ứng, Biến đổi khí hậu, Kịch bản biến đổi khí hậu, Mô hình Aquacrop, Mô hình SDSM. 